\title{
$\gamma$-Oryzanol の実験的動脈硬化症に及ぼす影響*
}

$\begin{array}{llllllll}\text { 藤 } & \text { 田劵 成** } & \text { 早 } & \text { 道 彦** } & \text { 岩 田 芳 郎** } \\ \text { 加 } & \text { 藤 } & \text { 左 } & \text { 志** } & \text { 牛 込 裕 代** } & \text { 大 原 清 仁** } \\ \text { 吉 荐 } & \text { 徳** } & \text { 葛 谷 文 男** } & & \end{array}$

I. 目 的

実験的高脂血症に対する $\gamma$-Oryzanol の作用を 前回の本学会で報告したが，今回は高コレステロ ール食飼育家鬼を用いて $\gamma$-Oryzanol Clofibrate の血清脂質に対する影響を検討した。

\section{II. 実験方法}

実験動物として体重 $3 \mathrm{Kg}$ 前後の雄性家兔を用 いた.コレステロール $1 \%$ 含有固型飼料を用い, $100 \mathrm{~g} /$ 日の飼料摂取量で 2 週間投与し，コレステ ロール值のバラッキが同じになるようこの時点で 4 群に分け, その後対照群にはコレステロール $1 \%$ 含有固型飼料を，被験薬群には対照群の飼料に $\gamma$-Oryzanol 原末を加えた固型飼料 $(0.3125 \%$ およ び $1.25 \%$ 含有) 2 種類と対照群の飼料に Clofibrate を加えた固型飼料 $(0.3125 \%)$ を $100 \mathrm{~g} /$ 日の摂取 量で 8 週間飼育した。薬物添加飼料飼育前, 飼育 4 週目, 8 週目に耳静脈より採血し血清を採取し て, Total Cholesterol は酵素法 (日本商事 Tc キ ット) ${ }^{2,3)}$ HDL-Cholesterol は Heparin Ca 法(日本 商事 HDL-C キット N) ${ }^{4}$ Triglyceride は Acetylceton 法 (和光純薬 Triglyceride テスト和光 $)^{5,6}$ Phospholipids 注酵素法 (日本商事 PL キット K) ${ }^{\text {?) }}$ $\beta$-Lipoprotein はWalton-Scott の葛谷変法, Lipid Peroxide は TBA 法9) により測定した. その他 2 〜 の血液生化学的検查も行った. 実験終了時の 10週に屠殺後大動脈を摘出してホルマリン固定後 Sudan II 染色を施行した.

*1980年12月, 日本動脈硬化学会昭和 55 年度冬季大会 において発表

** 名古屋大学老年科

\section{III. 実 験 成 績}

体重については Table 1 に示すが，薬物添加飼 料投与前の 0 週に比べ 8 週には各群とも体重増加 傾向がみられたが, 8 週では Control 群と比較して $\gamma$-Oryzanol $0.3125 \%$ 群のみ有意に増加傾向を示し た. Total Cholesterol については Table 2 に示す が, 各群とも 0 週に比べて 8 週には増加が見られ Fig. 1 に示す如く 8 週にて各群間に有意差はみら れなかった. HDL-Cholesterol については Table 2 に示すように Control 群と $\gamma$-Oryzanol $1.25 \%$ 群 では 0 週に比べ 8 週には増加を示したが， $\gamma$-Oryzanol $0.3125 \%$ 群と Clofibrate $0.3125 \%$ 群では減 少傾向を示した. Fi.g 2 に示すように 8 週にて Control 群に比較して, $\gamma$-Oryzanol $0.3125 \%$ 群が 有意に低下傾向を示した $(\mathrm{p}<0.05)$. Table 3 は Atherogenic Index を示しているが，各群間に有 意差はみられなかった. Table 4 には血清 Triglyceride Phospholipids $\beta$-Lipoprotein の推移を示し たが，いずれも 8 週にて各群間に有意差はみられ なかった. 血清過酸化脂質については Table 5 に 示した如く, 各群とも 0 週に比べ 8 週には増加傾

Table 1 Effect of $\gamma$-Oryzanol on Body Weight

\begin{tabular}{cccc}
\hline \multicolumn{2}{c}{ Week } & & \\
\hline Drug Administered & Week & 4 Week & 8 Week \\
\hline Control & $2.68 \pm 0.54^{*}$ & $2.76 \pm 0.4$ & $3.04 \pm 0.3$ \\
$\begin{array}{c}\gamma \text {-Oryzanol } \\
0.3125 \%\end{array}$ & $3.25 \pm 0.53$ & $3.2 \pm 0.45$ & $3.34 \pm 0.45$ \\
$\begin{array}{c}\gamma \text {-Oryzanol } \\
1.25 \%\end{array}$ & $2.9 \pm 0.32$ & $2.91 \pm 0.31$ & $3.12 \pm 0.28$ \\
$\begin{array}{c}\text { Clofibrate } \\
0.3125 \%\end{array}$ & $3.09 \pm 0.56$ & $3.06 \pm 0.58$ & $3.22 \pm 0.47$ \\
\hline
\end{tabular}


動脈硬化 Vol. 9 No. 5 December 1981

Table 2 Effect of $\gamma$-Oryzanol on Serum Total Cholesterol and HDL-Cholesterol

\begin{tabular}{ccccc}
\hline Week & & 0 Week & 4 Week & 8 Week \\
\hline Drug Administered & & & & $856 \pm 638$ \\
\hline Control & TC & $297 \pm 283^{*}$ & $382 \pm 473$ & $31.6 \pm 24.0$ \\
& HDL-C & $20.2 \pm 10.0$ & $32.2 \pm 17.0$ & $1105 \pm 719$ \\
r-Oryzanol & TC & $288 \pm 247$ & $555 \pm 407$ & $11.3 \pm 11.0$ \\
$0.3125 \%$ & HDL-C & $22.6 \pm 12.0$ & $24.8 \pm 8.0$ & $1136 \pm 907$ \\
r-Oryzanol & TC & $292 \pm 251$ & $400 \pm 405$ & $34.7 \pm 16.0$ \\
$1.25 \%$ & HDL-C & $25.9 \pm 9.0$ & $32.2 \pm 10.0$ & $1189 \pm 572$ \\
Clofibrate & TC & $286 \pm 248$ & $520 \pm 482$ & $22.0 \pm 16.0$ \\
$0.3125 \%$ & HDL-C & $25.4 \pm 10.0$ & $33.0 \pm 11.0$ & \\
\hline
\end{tabular}

$* \mathrm{mg} / \mathrm{d} l$ mean \pm S.D.

Table 3 Effect of $\gamma$-Oryzanol on Atherogenic Index

\begin{tabular}{|c|c|c|c|}
\hline Week & \multirow{2}{*}{0 Week } & \multirow{2}{*}{4 Week } & \multirow{2}{*}{8 Week } \\
\hline Drug Administered & & & \\
\hline Control & $15.25 \pm 19.18^{*}$ & $13.33 \pm 20.29$ & $56.34 \pm 79.23$ \\
\hline$\gamma$-Oryzanol $\quad 0.3125 \%$ & $13.41 \pm 12.65$ & $24.67 \pm 21.01$ & $97.49 \pm 62.35$ \\
\hline$\gamma$-Oryzanol $1.25 \%$ & $9.05 \pm 7.48$ & $11.45 \pm 13.32$ & $39.46 \pm 37.99$ \\
\hline Clofibrate $\quad 0.3125 \%$ & $10.08 \pm 10.78$ & $14.89 \pm 13.82$ & $64.19 \pm 67.81$ \\
\hline
\end{tabular}

* Atherogenic Index (TC-HDL-C/HDL-C) mean \pm S.D.

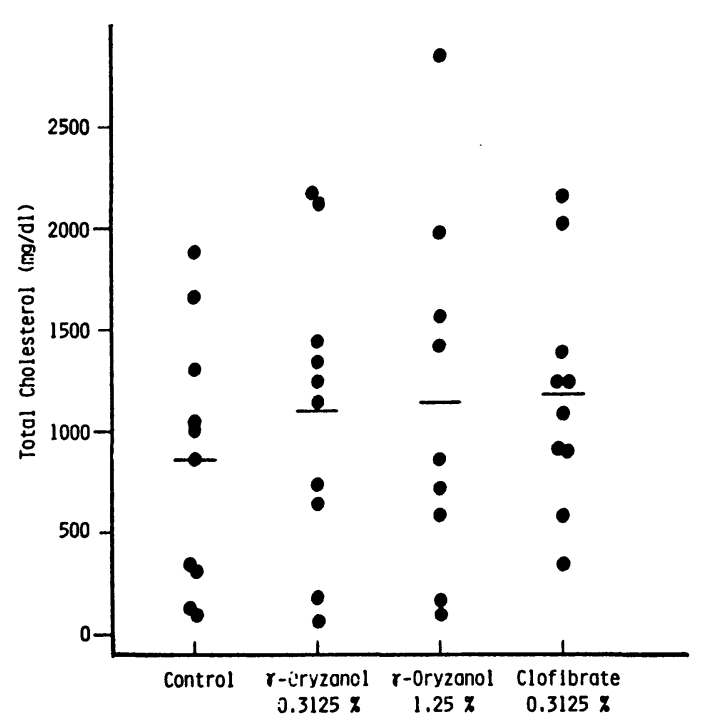

Fig. 1 Effect of $\gamma$-Oryzanol on Serum Total Cholesterol at 8 Weeks.

向がみられ Fig. 3 に示すよう 8 週にて各群間に有 意差はみられなかった. その他血液生化学検査に ついては Tble 6, Table 7, Table 8 に示すように各 群と\& A/G 比の低下, AL-P の上昇, LDH の上昇, T-Bil の上昇, 血糖の上昇を認めた. 以上の如く

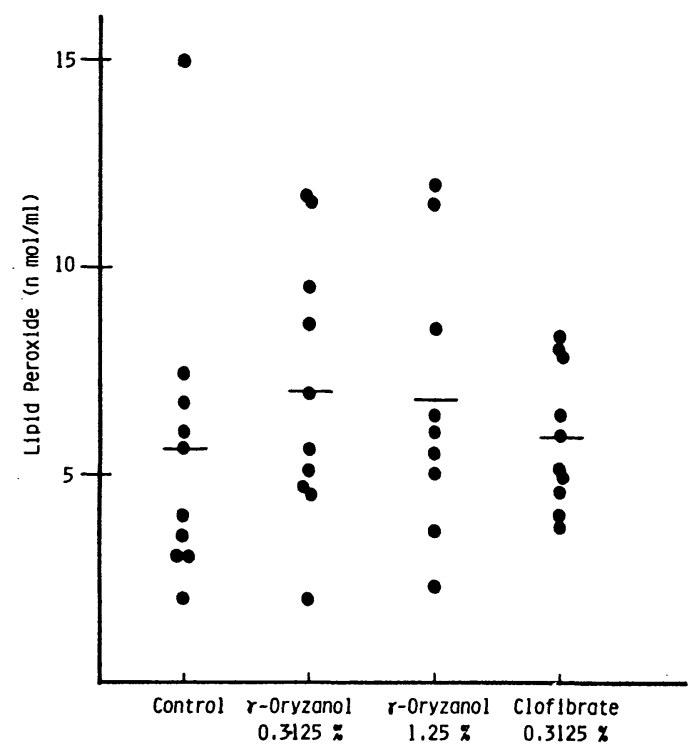

Fig. 2 Effect of $\gamma$-Oryzanol on Serum Lipid Peroxide at 8 Weeks.

肝障害を推測せしめる結果が得られた。これは脂 肪肝によるものと思われる. 各検査項目について 各群間に有意差は見られなかった. 各群の Aorta の Sudan II 染色所見は Fig. 4, Fig. 5, Fig. 6, Fig. 7 に示す如くで Control 群に比し薬物投与群に脂 
$\gamma$-Oryzanol の実験的動脈硬化症に及ぼす影響

Table 4 Effect of $\gamma$-Oryzanol on Serum Lipid Level

\begin{tabular}{clrrr}
\hline & Week & \multirow{2}{*}{0 Week } & 4 Week & \multicolumn{1}{c}{8 Week } \\
\hline Drug Administered & & & & \\
\hline & TG & $56 \pm 71^{*}$ & $49 \pm 28$ & $120 \pm 158$ \\
Control & PL & $151 \pm 81$ & $249 \pm 197$ & $452 \pm 286$ \\
& B-L & $737 \pm 792$ & $877 \pm 956$ & $1186 \pm 994$ \\
$\gamma$-Oryzanol & TG & $36 \pm 26$ & $67 \pm 42$ & $138 \pm 152$ \\
$0.3125 \%$ & PL & $138 \pm 82$ & $301 \pm 210$ & $485 \pm 347$ \\
& B-L & $787 \pm 725$ & $1169 \pm 976$ & $1887 \pm 1255$ \\
$\gamma$-Oryzanol & TG & $28 \pm 14$ & $68 \pm 51$ & $144 \pm 208$ \\
$1.25 \%$ & PL & $151 \pm 91$ & $317 \pm 213$ & $573 \pm 434$ \\
& B-L & $800 \pm 735$ & $1165 \pm 970$ & $1909 \pm 1402$ \\
Clofibrate & TG & $53 \pm 63$ & $55 \pm 41$ & $140 \pm 133$ \\
$0.3125 \%$ & PL & $144 \pm 70$ & $271 \pm 158$ & $616 \pm 287$ \\
& B-L & $768 \pm 717$ & $1100 \pm 792$ & $2086 \pm 1198$ \\
\hline
\end{tabular}

${ }^{*} \mathrm{mg} / \mathrm{d} l$ mean \pm S.D.

Table 5 Effect of $\gamma$-Oryzanol on Serum Lipid Peroxide

\begin{tabular}{cccc}
\hline \multicolumn{1}{c}{ Week } & 0 Week & 4 Week & 8 Week \\
\cline { 1 - 3 } $\begin{array}{c}\text { Drug } \\
\text { Administered }\end{array}$ & & & \\
\hline $\begin{array}{c}\text { Control } \\
\text { x-Oryzanol }\end{array}$ & $3.2 \pm 1.1^{*}$ & $4.1 \pm 1.3$ & $5.6 \pm 3.7$ \\
$0.3125 \%$ & $4.4 \pm 1.1$ & $7.0 \pm 3.2$ \\
$\begin{array}{c}\text { x-Oryzanol } \\
1.25 \%\end{array}$ & $3.6 \pm 1.1$ & $4.1 \pm 1.8$ & $6.8 \pm 3.3$ \\
$\begin{array}{c}\text { Clofibrate } \\
0.3125 \%\end{array}$ & $3.5 \pm 1.2$ & $3.8 \pm 1.2$ & $5.9 \pm 1.7$ \\
\hline
\end{tabular}

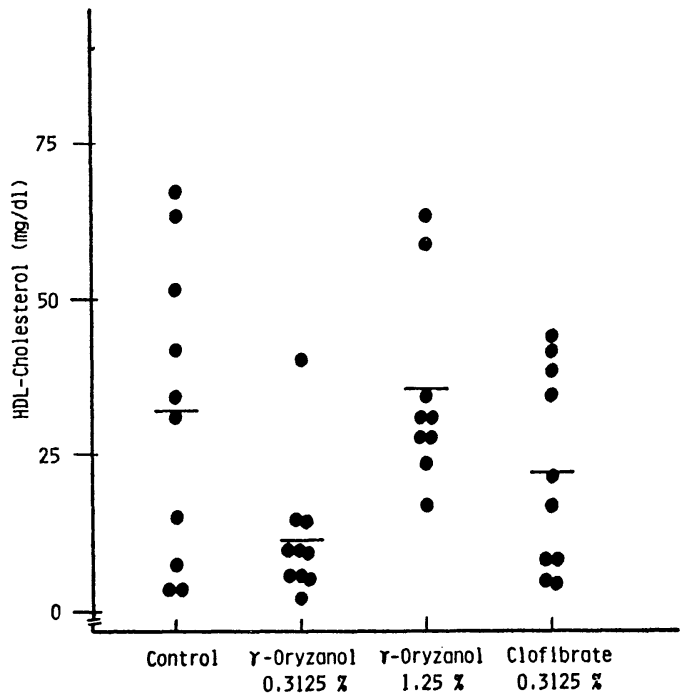

Fig. 3 Effect of $\gamma$-Oryzanol on Serum HDL-Cholesterol at 8 Weeks.

Table 6 Data of Blood Chemistry

\begin{tabular}{|c|c|c|c|c|}
\hline & Week & & & \\
\hline \multicolumn{5}{|c|}{ Drug Administered } \\
\hline & TP & $9.1 \pm 6.0^{*}$ & $12.9 \pm 9.7$ & $18.9 \pm 9.9$ \\
\hline \multirow[t]{2}{*}{ Control } & $\mathrm{A} / \mathrm{G}$ & $1.2 \pm 0.5$ & $2.4 \pm 4.3$ & $0.7 \pm 0.6$ \\
\hline & ALP & $21.1 \pm 24.0$ & $38.9 \pm 38.3$ & $62.6 \pm 41.3$ \\
\hline$\gamma$-Oryzanol & TP & $10.5 \pm 6.6$ & $14.6 \pm 8.8$ & $22.4 \pm 11.3$ \\
\hline \multirow[t]{2}{*}{$0.3125 \%$} & $\mathrm{~A} / \mathrm{G}$ & $1.0 \pm 0.5$ & $0.9 \pm 0.6$ & $0.6 \pm 0.5$ \\
\hline & ALP & $18.0 \pm 21.3$ & $41.3 \pm 39.5$ & $76.6 \pm 41.4$ \\
\hline$\gamma$-Oryzanol & TP & $8.2 \pm 3.0$ & $14.6 \pm 9.9$ & $22.0 \pm 17.8$ \\
\hline \multirow{2}{*}{$1.25 \%$} & $\mathrm{~A} / \mathrm{G}$ & $1.2 \pm 0.5$ & $0.9 \pm 0.6$ & $0.7 \pm 0.4$ \\
\hline & ALP & $18.4 \pm 13.2$ & $49.0 \pm 48.4$ & $68.2 \pm 62.3$ \\
\hline Clofibrate & TP & $9.6 \pm 6.3$ & $12.6 \pm 6.0$ & $24.2 \pm 13.3$ \\
\hline \multirow[t]{2}{*}{$0.3125 \%$} & $\mathrm{~A} / \mathrm{G}$ & $1.1 \pm 0.5$ & $0.9 \pm 0.5$ & $0.5 \pm 0.2$ \\
\hline & ALP & $21.6 \pm 23.1$ & $38.6 \pm 28.0$ & $75.9 \pm 42.3$ \\
\hline
\end{tabular}

* mean \pm S.D. 
動脈硬化 Vol.9 No. 5 December 1981

Table 7 Data of Blood Chemistry

\begin{tabular}{|c|c|c|c|c|}
\hline & Week & $0 \mathbf{W}$ - & 1 W/ & $8 \mathrm{~W}$ \\
\hline \multicolumn{5}{|c|}{ Drug Administered } \\
\hline & GOT & $34.7 \pm 9.3^{*}$ & $37.0 \pm 15.7$ & $44.8 \pm 14.5$ \\
\hline \multirow[t]{2}{*}{ Control } & GPT & $28.9 \pm 13.5$ & $42.0 \pm 25.1$ & $33.5 \pm 10.9$ \\
\hline & LDH & $633 \pm 285$ & $467 \pm 209$ & $556 \pm 187$ \\
\hline$\gamma$-Oryzanol & GOT & $34.3 \pm 15.0$ & $41.1 \pm 19.9$ & $45.3 \pm 19.6$ \\
\hline \multirow[t]{2}{*}{$0.3125 \%$} & GPT & $43.7 \pm 28.8$ & $36.8 \pm 11.9$ & $26.3 \pm 17.4$ \\
\hline & LDH & $485 \pm 154$ & $534 \pm 213$ & $565 \pm 122$ \\
\hline$\gamma$-Oryzanol & GOT & $92.6 \pm 97.6$ & $116.1 \pm 235.1$ & $51.2 \pm 26.9$ \\
\hline \multirow[t]{2}{*}{$1.25 \%$} & GPT & $70.9 \pm 74.8$ & $42.4 \pm 24.9$ & $32.9 \pm 15.5$ \\
\hline & LDH & $615 \pm 187$ & $494 \pm 184$ & $830 \pm 446$ \\
\hline Clofibrate & GOT & $48.8 \pm 39.8$ & $42.4 \pm 13.1$ & $55.0 \pm 15.9$ \\
\hline \multirow[t]{2}{*}{$0.3125 \%$} & GPT & $43.4 \pm 32.6$ & $40.5 \pm 21.1$ & $39.1 \pm 16.0$ \\
\hline & LDH & $682 \pm 290$ & $674 \pm 262$ & $540 \pm 174$ \\
\hline
\end{tabular}

* mean \pm S.D.

Table 8 Data of Blood Chemistry

\begin{tabular}{|c|c|c|c|c|}
\hline & Week & & & \\
\hline \multicolumn{5}{|c|}{ Drug Administered } \\
\hline & T-BI & $1.1 \pm 2.1^{*}$ & $3.7 \pm 5.8$ & $6.7 \pm 7.3$ \\
\hline \multirow[t]{2}{*}{ Control } & BS & $160 \pm 71$ & $226 \pm 140$ & $290 \pm 150$ \\
\hline & BUN & $18.3 \pm 8.0$ & $15.2 \pm 3.1$ & $17.3 \pm 2.1$ \\
\hline$\gamma$-Oryzanol & $\mathrm{T}-\mathrm{BI}$ & $1.0 \pm 1.5$ & $4.3 \pm 6.4$ & $7.7 \pm 7.4$ \\
\hline \multirow[t]{2}{*}{$0.3125 \%$} & BS & $163 \pm 94$ & $261 \pm 138$ & $357 \pm 168$ \\
\hline & BUN & $15.6 \pm 1.7$ & $14.9 \pm 2.9$ & $15.6 \pm 4.0$ \\
\hline$\gamma$-Oryzanol & T-BI & $0.5 \pm 0.6$ & $5.0 \pm 6.9$ & $7.3 \pm 8.3$ \\
\hline \multirow[t]{2}{*}{$1.25 \%$} & BS & $155 \pm 58$ & $244 \pm 179$ & $314 \pm 231$ \\
\hline & BUN & $14.6 \pm 5.9$ & $15.7 \pm 3.3$ & $16.8 \pm 2.2$ \\
\hline Clofibrate & T-BI & $0.7 \pm 1.0$ & $2.5 \pm 2.6$ & $7.8 \pm 6.9$ \\
\hline \multirow[t]{2}{*}{$0.3125 \%$} & BS & $159 \pm 64$ & $224 \pm 106$ & $344 \pm 170$ \\
\hline & BUN & $15.8 \pm 2.4$ & $17.5 \pm 2.4$ & $18.0 \pm 2.4$ \\
\hline
\end{tabular}

*mean \pm S.D.

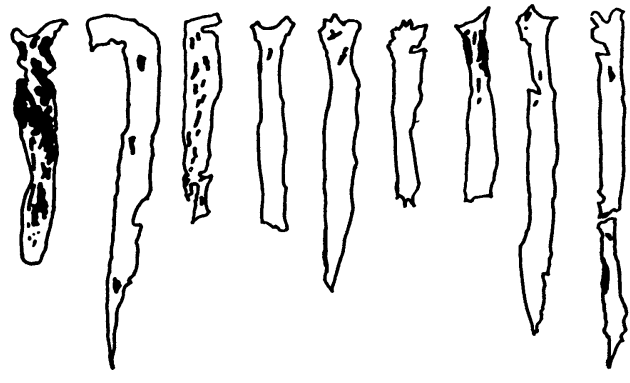

Control ( $1 \%$ Cholesterol chow)

Fig. 4 Macroscopic finding of rabbit's aorta.
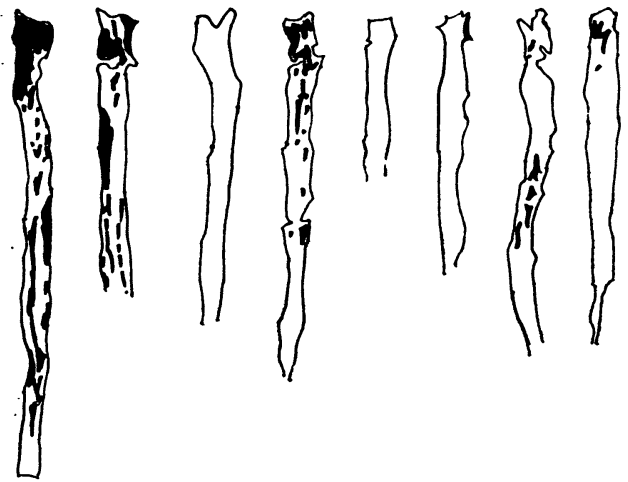

$\gamma$-Oryzanol $0.3125 \%$

Fig. 5 Macroscopic finding of rabbit's aorta. 


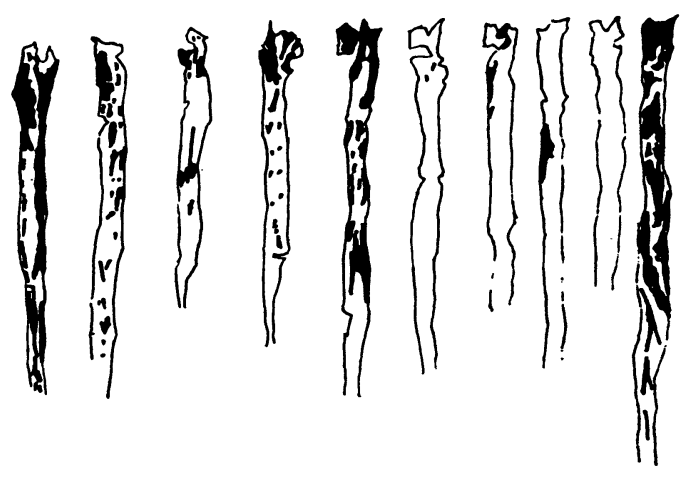

$\gamma$-Oryzanol $1.25 \%$

Fig. 6 Macroscopic finding of rabbit's aorta.
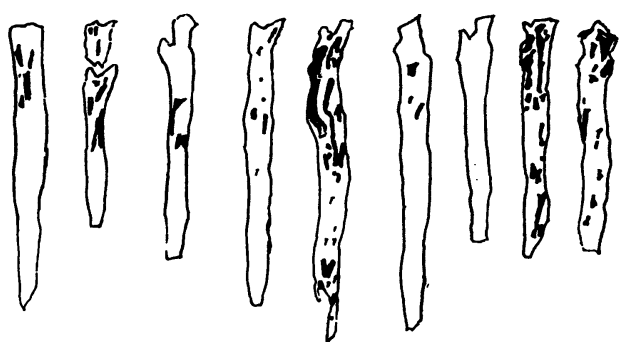

Clofibrate $0.3125 \%$

Fig. 7 Macroscopic finding of rabbit's aorta.

肪沈着の抑制傾向は認められなかった.

\section{IV. 考 察}

前回高コレステロール食飼育ラットを用いた実 験では $\gamma$-Oryzanol に Total Cholesterol おょび血 清過酸化脂質の低下作用のある事が明らかとなっ たが，高コレステロール食飼育家鬼を用いた今回 の実験ではこれらの作用は認められなかった．今 回は生化学的にも形態学的にも家鬼の個体差が著 しかったことと長期大量コレステロールを負荷し
たためにこれら薬剤の効果が消殺されたものと思 われる。

\section{V. 結 論}

高コレステロール食飼育家鬼を用い各種濃度の $\gamma$-Oryzanol 添加飼料および Clofibrate 添加飼料 を経口投与し血清脂質に対する影響を調べたが， r-Oryzanol と Clofibrate は, Total Cholesterol, HDL-Cholesterol などの血清脂質および過酸化脂 質に対して明らかな作用が認められなかった。ま た大動脈におこった脂肪沈着に対しても抑制する 傾向を認めなかった.

\section{文献}

1) 葛谷文男, 他：実験的高脂血症ラットに対する $\gamma$ Oryzanol の作用. Geriatric Medicine 18: 519-524 (1980).

2) 正路喜代美, 他: Cholesterol: Oxygen Oxireduetase を用いる血清コレステロールの新しい測定法の検討. 臨床病理 21: 85 (1957).

3）亀野靖郎，他: Sterol 3B Oxidoreductase に関する 研究, 特にその特性ならびに血清コレステロール定 量法への応用. 臨床化学シンポジウム, 13集：120 121 (1973).

4) 櫻林郁之介：HDL, LDL コレステロール 測定法. 綜合臨牃 28: 2045-2049 (1979).

5) Royen, M. E., et al: A Simplified Semiantomated Assay far Plasma Triglycerides. Anal. Biochem., 29: 405-416 (1969).

6) 福井 嚴：血清脂質測定の問題点. 臨床病理 23: 31-39 (1975).

7) 吉岡光考, 他：血清燐脂質定量法の検討一特に 2 つ の試法について一. 臨床病理 10: 194-198 (1962).

8) 葛谷文男: 抗凝固剤の薬理作用と臨床応用. 綜合臨 牀 15: 274-287 (1966).

9) 真杉文紀, 他: Sodium Dodetylsulphate 可溶化に よる肝チオバルビッール酵值とビタミン $\mathrm{E}$, 薬物に よるその変動. ビタミン 51: 21-29 (1977). 


\title{
Summary
}

\section{Studies on Effect of $\boldsymbol{\gamma}$-Oryzanol on Serum Lipid Levels and Lipid Peroxide Level in the Hypercholesterolemic Rabbits}

\author{
Katsunaru FujtTa, Michihiro Hayakawa, Yoshio Iwata, Yasuyo Ushigome, \\ Shoshi Kato, Kiyoji Oohara, Noboru Yoshimine and Fumio KuzuYa
}

\author{
Department of Geriatrics, Nagoya University, School of Medicine
}

\begin{abstract}
We already reported the effects of $\gamma$-Oryzanol on serum lipid metabolism in cholesterol-fed rats. The results implied that administration of $\gamma$ Oryzanol inhibited the increase of serum total cholesterol and serum lipid peroxide levels caused by cholesterol feeding. In the present study, we have observed the effects of $\gamma$-Oryzanol on lipid metabolism and pathological changes of aortae in cholesterol-fed rabbits, using clofibrate for comparison. Male rabbits were fed on a high cholesterol diet for 10 weeks in the following manner: (1) $1 \%$
\end{abstract}

high cholesterol diet. (2) $1 \%$ high cholesterol diet for 2 weeks, then after $1 \%$ high cholesterol diet plus $0.3125 \% \gamma$-Oryzanol for 8 weeks. (3) $1 \%$ high cholesterol diet for 2 weeks, then after $1 \%$ high cholesterol diet plus $1.25 \% \gamma$-Oryzanol for 8 weeks. (4) $1 \%$ high cholesterol diet 2 weeks, then after $1 \%$ high cholesterol diet plus $0.3125 \%$ clofibrate. Neither $\gamma$-Oryzanol nor clofibrate affected the levels of serum lipid and lipid peroxide in cholesterol-fed rabbits, reduced the atherosclerotic intimal involvement. 